\title{
Preimplantation genetic diagnosis of Von Hippel-Lindau disease cancer syndrome by combined mutation and segregation analysis
}

\author{
Denilce R. Sumita ${ }^{1}$, José Cláudio C. Rocha ${ }^{2}$, Assumpto Iaconelli Jr. ${ }^{3}$, Edson Borges Jr. ${ }^{3}$ \\ and Lygia V. Pereira ${ }^{1}$ \\ ${ }^{I}$ Departamento de Genética e Biologia Evolutiva, Instituto de Biociências, Universidade de São Paulo, \\ São Paulo, SP, Brasil. \\ ${ }^{2}$ Departamento de Oncogenética, Hospital do Câncer A.C. Camargo, São Paulo, SP, Brazil. \\ ${ }^{3}$ Fertility - Assisted Fertilization Center, São Paulo, SP, Brazil.
}

\begin{abstract}
Von Hippel-Lindau (VHL) disease is an autosomal dominant cancer syndrome, associated with the development of tumors and cysts in multiple organ systems, whose expression and age of onset are highly variable. The VHL disease tumor suppressor gene (VHL) maps to 3p25-p26 and mutations ranging from a single base change to large deletions have been detected in patients with VHL disease. We developed a single cell PCR protocol for preimplantation genetic diagnosis (PGD) of VHL disease to select unaffected embryos on the basis of the detection of the specific mutation and segregation analysis of polymorphic linked markers. Multiplex-nested PCR using single buccal cells of an affected individual were performed in order to test the accuracy and reliability of this single-cell protocol. For each locus tested, amplification efficiency was $83 \%$ to $87 \%$ and allelic drop-out rates ranged from $12 \%$ to $8 \%$. Three VHL disease PGD cycles were performed on cells from a couple with paternal transmission of a 436delC mutation in exon 2 of the $V H L$ gene, leading to the identification of three unaffected embryos. Independent of the mutation present, this general PGD protocol for the diagnosis of VHL disease can be used in families informative for either the D3S1038 or D3S1317 microsatellite markers.
\end{abstract}

Key words: multiplex PCR, preimplantation genetic diagnosis, von Hippel-Lindau disease, VHL gene.

Received: March 10, 2006; Accepted: September 13, 2006.

Von Hippel-Lindau (VHL) disease is an autosomal dominant inherited familial cancer syndrome predisposing to retinal and central nervous system hemangioblastomas, renal cell carcinoma and renal cysts, phaeochromocytoma and pancreatic cysts and tumors, epididimal cysts and endolymphatic sac tumors (Maher et al., 1990; 1991; Decker, 1997). The disease has an incidence of approximately 1 in 36000 live births, and a penetrance of over $90 \%$ by 65 years of age (Maher et al., 1990; 1991; Neumann, 1991). Mutations in the von Hippel-Lindau VHL gene (Online Mendelian Inheritance in Man (OMIM) accession number 608537), a tumor suppressor gene on the short arm of chromosome 3 (3p25-26), causes VHL disease (Latif et al., 1993), with most of the cases are inherited. Advances in genetic testing for the disease include qualitative and quan-

Send correspondence to Lygia V. Pereira. Departamento de Genética e Biologia Evolutiva, Instituto de Biociências, Universidade de São Paulo, Rua do Matão, 277/350, 05508-900 São Paulo, SP, Brazil. E-mail: Ipereira@usp.br.

*Present address: Genomic Engenharia Molecular, São Paulo, SP, Brazil. titative Southern blotting, which has been added to DNA sequence analysis (Lonser et al., 2003). In addition, polymorphic markers close to the VHL gene can be used to identify at risk individuals in a VHL disease family by segregation analysis. For this purpose, the most informative microsatellite markers are D3S1317, D3S1038, D3S587 and D3S1435, all within $500 \mathrm{~kb}$ of the $V H L$ gene (Richards et al., 1995). Although highly penetrant, VHL disease presents great clinical variability. In addition, no phenotypegenotype correlation has been established so far for the disease, rendering interruption of pregnancy of an affected fetus a difficult decision and preimplantation genetic diagnosis (PGD) an interesting option for at risk couples. One case of PGD for VHL disease has been described which relied on detection of the specific mutation and segregation analysis of a microsatellite marker linked to the $V H L$ gene (Rechitsky et al., 2002).

In this paper we describe the development of a novel PGD protocol for VHL disease and the use of this protocol in a clinical case. A combination of specific mutation and segregation analysis of two closely linked microsatellite 
markers reduced the effect of possible allelic drop-out (ADO), thus increasing the number of embryos diagnosed and allowing the use of the protocol in a greater number of families with VHL disease.

Ethical approval for this study was granted by the Ethical Committee of the Instituto de Biociências of the Universidade de São Paulo (São Paulo, Brasil) and informed consent was obtained from the patients. The patients were a couple consisting of an unaffected normal female (coded II-2, generally called the 'spouse' in the text) who was the spouse of a patient (coded II-1) being treated for VHL disease at Hospital do Câncer A. C. Camargo (São Paulo, Brasil) (Figure 1a). Patient II-1 was initially thought to be an isolated case of VHL disease and showed central nervous system hemangioblastomas (cerebella and spinal cord) diagnosed since age 11, retinal angiomas, renal adenomas and multiple cysts (including in the epididymis) and who had a 436delC mutation in exon 2 of the $V H L$ gene (Rocha et al., 2003). However, genetic analysis of the parents of patient II-1 revealed that the mutation was in fact inherited from his mother, who was initially thought to be unaffected but was found to have small tumors in various organs after clinical re-examination at age 54 (Rocha et al., 2003).

Segregation analysis with microsatellite markers was accomplished by testing the D3S1038, D3S1317 and D3S1435 microsatellite loci linked to the VHL gene to determine which of them were informative enough to be used in PGD. The polymerase chain reaction (PCR) mixture consisted of $100 \mathrm{ng}$ of genomic DNA extracted from peripheral blood lymphocytes of family members by a standard method (Miller et al., 1988), $50 \mathrm{mM} \mathrm{KCl,} 1.5 \mathrm{mM}$ of $\mathrm{MgCl}_{2}, 10 \mathrm{mM}$ Tris-HCl (pH 8.3), $200 \mu \mathrm{M}$ of each nucleotide (dATP, dCTP, dGTP and dTTP: Amersham-Pharmacia), $0.6 \mu \mathrm{M}$ of each primer (D3S1038-F and D3S1038-R, or D3S1317-F and D3S1317-R, or D3S1435-F and D3S1435-R: Table 1) , $1.25 \mu \mathrm{L}$ of dimethyl sulfoxide (DMSO: SIGMA, USA), 1 unit of Taq DNA polymerase (Amersham-Pharmacia) in a final reaction volume of $25 \mu \mathrm{L}$. The PCR was carried out using an initial denaturation step of $5 \mathrm{~min}$ at $94{ }^{\circ} \mathrm{C}$, followed by 30 cycles of $1 \mathrm{~min}$ (a)

$$
\begin{aligned}
& \text { D3S1038: } 16 \\
& \text { D3S1317: } 1 \\
& \text { D3S1435: } 1 \\
& \text { VHL: } \quad \mathrm{N}
\end{aligned}
$$
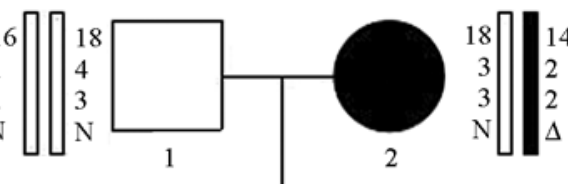

II

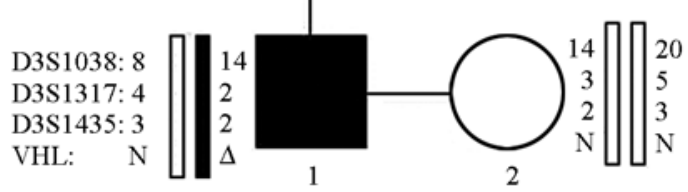

(c)
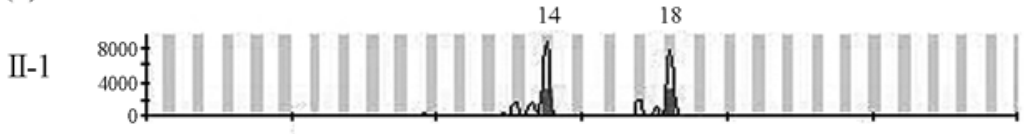

II-2

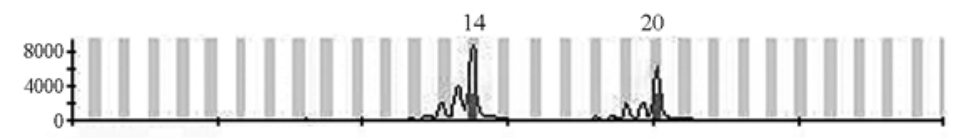

B3

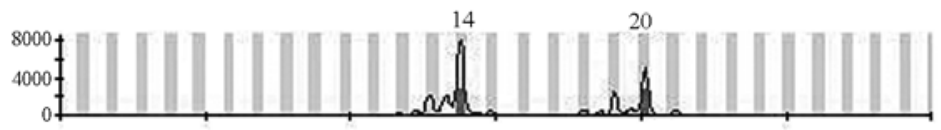

B7

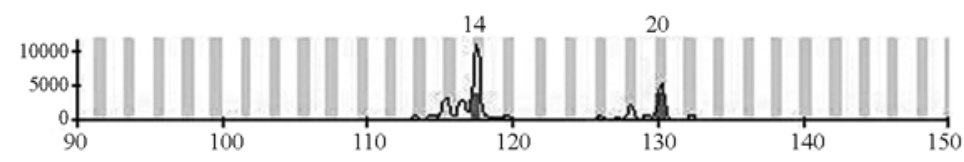

Figure 1 - Pedigree of the family with hereditary Von Hippel-Lindau (VHL) disease and analysis of blastomeres from the first in vitro fertilization (IVF) cycle. (a) Haplotype of linked microsatellite markers D3S1038, D3S1317 and D3S1435, and genotype regarding the 436delC mutation of the VHL gene ( $\mathrm{N}=$ normal allele; $\Delta=$ mutant allele) are shown next to each individual. The affected individual (II-1) and his normal spouse (II-2) were informative for markers D3S1038 and D31317. (b) Analysis of 436delC mutation in blastomeres from embryos 2 (B2), 3 (B3), 5 (B5) and 7 (B7) of the first IVF cycle (blastomere number in parentheses). The mutation creates an $A l u \mathrm{I}$ restriction site generating $144 \mathrm{bp}$ and $83 \mathrm{bp}$ fragments from the normal $436 \mathrm{delC} 288 \mathrm{bp}$ fragment upon digestion with $A l u \mathrm{I}$. $\mathrm{L}=1 \mathrm{~kb}$ plus DNA Ladder (Invitrogen). (c) Electropherogram of microsatellite D3S1038 analysis of blastomeres from embryos 3 (B3) and 7 (B7). The lengths (bp) of the amplified products is represented on the bottom of the electropherograms. Allele numbers are indicated on the top of the corresponding peaks. 
at $94{ }^{\circ} \mathrm{C}, 2 \mathrm{~min}$ at $54{ }^{\circ} \mathrm{C}, 1 \mathrm{~min}$ at $72{ }^{\circ} \mathrm{C}$ and a final elongation step of $10 \mathrm{~min}$ at $72{ }^{\circ} \mathrm{C}$. The PCR products were separated on $8 \%(\mathrm{w} / \mathrm{v})$ acrylamide gels and stained with silver nitrate. In this family only the D3S1038 (allele 14) and D3S1317 (allele 2) were informative and segregated with the mutation (Figure 1a).

To determine PCR efficiency and ADO frequency for the three microsatellite loci we used individual buccal cells as a single cell analysis test system. The buccal cells were obtained by gently scraping the inside of the cheek with a clean wooden applicator stick at least 30 min after eating or drinking and twirling the stick was gently in a tube containing $0.5 \mathrm{~mL}$ of $0.9 \%(\mathrm{w} / \mathrm{v})$ sodium chloride. The sample was centrifuged and the pellet washed twice with $0.9 \%(\mathrm{w} / \mathrm{v})$ sodium chloride and the pellet resuspended in $0.2 \mathrm{~mL}$ of $\mathrm{Ca}^{2+}$ and $\mathrm{Mg}^{2+}$-free phosphate-buffered saline (PBS). Single buccal cells were isolated and rinsed twice in different drops of PBS and then transferred to a $0.2 \mathrm{~mL}$ PCR tube containing $2 \mu \mathrm{L}$ of PBS containing $2 \mu \mathrm{L}$ of a solution containing $125 \mu \mathrm{g} \mathrm{mL}^{-1}$ proteinase $\mathrm{K}$ (SIGMA, USA), $1 \mu \mathrm{L}$ of $17 \mu \mathrm{M}$ sodium dodecyl sulfate (SDS: SIGMA, USA) and $50 \mu \mathrm{L}$ of mineral oil (SIGMA, USA). The cells were incubated for $15 \mathrm{~min}$ at $65^{\circ} \mathrm{C}$ followed by $8 \mathrm{~min}$ at $99{ }^{\circ} \mathrm{C}$ and stored at $-20{ }^{\circ} \mathrm{C}$ until the multiplex PCR was performed.

The multiplex PCR reaction mixture consisted of $60 \mathrm{mM} \mathrm{KCl}, 1.8 \mathrm{mM} \mathrm{MgCl}_{2}, 12 \mathrm{mM}$ Tris- $\mathrm{HCl}$ (pH 8.3), $200 \mu \mathrm{M}$ of each nucleotide (described above), $0.6 \mu \mathrm{M}$ of each primer (VHL2-A, VHL2-B, D3S1038-F, D3S1038-B, D3S1317-F and D3S1317-B: Table 1), $1.25 \mu \mathrm{L}$ of DMSO and 1.5 units of Taq DNA polymerase in a final reaction volume of $25 \mu \mathrm{L}$. The first round of PCR was performed using an initial denaturation step of $5 \mathrm{~min}$ at $95^{\circ} \mathrm{C}$, followed by 20 cycles of $1 \mathrm{~min}$ at $94^{\circ} \mathrm{C}, 2 \mathrm{~min}$ at $50^{\circ} \mathrm{C}, 1 \mathrm{~min}$ at $72^{\circ} \mathrm{C}$ and a final elongation step of $10 \mathrm{~min}$ at $72^{\circ} \mathrm{C}$. Nested amplification was accomplished by removing $2.5 \mu \mathrm{L}$ of the product of the first PCR reaction and adding this to fresh re- action tubes containing $50 \mathrm{mM} \mathrm{KCl}, 1.5 \mathrm{mM}$ of $\mathrm{MgCl}_{2}$, $10 \mathrm{mM}$ Tris- $\mathrm{HCl}$ (pH 8.3), $200 \mu \mathrm{M}$ of each nucleotide (described above), $0.6 \mu \mathrm{M}$ of each inner primer (VHL2-C and VHL2-D, or D3S1038-F and D3S1038-R, or D3S1317-F and D3S1317-R: Table 1), 1.25 $\mu \mathrm{L}$ of DMSO and 1 unit of Taq DNA polymerase in a final reaction volume of $25 \mu \mathrm{L}$. The PCR was performed with an initial denaturation step of 5 min at $95^{\circ} \mathrm{C}$, followed by 30 cycles of $1 \mathrm{~min}$ at $94^{\circ} \mathrm{C}$, 2 min at $54^{\circ} \mathrm{C}, 1 \mathrm{~min}$ at $72^{\circ} \mathrm{C}$ and a final elongation step of $10 \mathrm{~min}$ at $72^{\circ} \mathrm{C}$.

Since patient II-1 (Figure 1a) was azoospermic, spermatozoa were retrieved by testicular sperm aspiration on the same day as follicular puncture was carried out on his spouse. Intracytoplasmic spermatozoa injection (ICSI) procedure was performed with metaphase II oocytes according to the technique described by Palermo et al. (1992). Embryo biopsy was carried out early in the morning of the third day after fertilization as described by Verlinsky and Kuliev (2002). Blastomeres were rinsed twice in different drops of PBS and collected in a $0.2 \mathrm{~mL}$ PCR tube. To monitor contamination For each blastomere, one $2 \mu \mathrm{L}$ blank of the last washing droplet was transferred to a PCR tube. For analysis of the 436delC mutation and D3S1038 marker in the blastomeres the D3S1317-F and D3S1317-B primers were omitted from the amplification mixture described above.

From patient II-1 we analyzed 60 single buccal cells containing the 436delC mutation (Table 2). These results showed that the addition of a third locus did not increase the frequency of a conclusive diagnosis, and therefore blastomere genotyping was performed with only the D3S1038 marker and the 436delC mutation (Table 2).

The analysis of mutation $436 \mathrm{delC}$ at exon 2 was based on the created $A l u \mathrm{I}$ restriction site that yields two fragments ( $83 \mathrm{bp}$ and $144 \mathrm{bp}$ ) after digestion of the PCR products with the AluI restriction enzyme. We used 1 unit of AluI restriction enzyme (Amersham-Pharmacia) in a to-

Table 1 - Sequence of primers used for preimplantation genetic diagnosis of Von Hippel-Lindau disease.

\begin{tabular}{|c|c|c|}
\hline Primer & Sequence & Reference \\
\hline VHL2-A & 5' CTC CCA AAG TGC TGG GAT T 3' & This paper \\
\hline VHL2-B & 5' CAA AAA TTG AGA ACT GGG CTT A 3' & This paper \\
\hline VHL2-C & 5’ TGC CCA GCC ACC GGT GTG 3’' & Rocha et al., 2003 \\
\hline VHL2-D & 5' GTC TAT CCT GTA CTT ACC ACA ACA 3' & Rocha et al., 2003 \\
\hline D3S1317-F & 5' TAC AAG TTC AGT GGA GAA CC 3' & Li et al., 1993 \\
\hline D3S1317-B & 5' TTT TCC TTT CCC TCC TAA TCC 3' & This paper \\
\hline D3S1317-R & 5' CCT CCA GGC CAT ACA CAG TCA 3' & Li et al., 1993 \\
\hline D3S1435-F & 5' TGG ATA CAT TAG TAT ACT GAA TT 3' & Li et al., 1993 \\
\hline D3S1435-R & 5’ TTA GAC GGA AGC AAG GAA GG 3’ & Li et al., 1993 \\
\hline D3S1038-F & 5' TCC AGT AAG AGG CTT CCT AG 3' & Jones et al., 1992 \\
\hline D3S1038-B & 5' CAC GGG AGT CTA CAG CTT GG 3' & This paper \\
\hline D3S1038-R ${ }^{(*)}$ & 5' AAA GGG GTT CAG GAA ACC TG 3' & Jones et al, 1992 \\
\hline
\end{tabular}

(*) Primer labeled with fluorescence FAM. 
Table 2 - Polymerase chain reaction amplification efficiency and allelic drop-out rate of the Von Hippel-Lindau (VHL) gene and the D3S1038 and D3S1317 microsatellites in single cells.

\begin{tabular}{lccc}
\hline Locus & $\begin{array}{c}\text { Total number of } \\
\text { cells analyzed }\end{array}$ & $\begin{array}{c}\text { Amplification } \\
\text { efficiency }(\%)^{\dagger}\end{array}$ & $\begin{array}{c}\text { Allelic drop-out } \\
\text { frequency }(\%)^{\dagger}\end{array}$ \\
\hline$V H L$ & 60 & $83 \%(50 / 60)$ & $12 \%(6 / 50)$ \\
D3S1038 & 60 & $87 \%(52 / 60)$ & $8 \%(4 / 52)$ \\
D3S1317 & 60 & $87 \%(52 / 60)$ & $31 \%(11 / 36)$ \\
\hline
\end{tabular}

Numbers in parentheses show the number of positive cells as a function of the total number of cells analyzed.

tal reaction volume of $20 \mu \mathrm{L}$ to digest $10 \mu \mathrm{L}$ aliquots of nested-PCR product of DNA from single-cell blastomere or buccal cell and separated the products in $2 \%(\mathrm{w} / \mathrm{v})$ agarose gels stained with ethidium bromide or $6 \%(\mathrm{w} / \mathrm{v})$ acrylamide gels stained with silver nitrate. For analysis of the D3S1038 microsatellite $2 \mu \mathrm{L}$ of a 1:10 dilution of the nested-PCR product were mixed with $2 \mu \mathrm{L}$ of $0.1 \%(\mathrm{v} / \mathrm{v})$ aqueous Tween 20 (SIGMA, USA) and $1 \mu \mathrm{L}$ of a size standard and subjected the mixture to electrophoreses on a MegaBACE 1000 (Amersham-Pharmacia). Results were analyzed with the Genetic Profiler software supplied by Amersham-Pharmacia.

The couple was submitted to three cycles of in vitro fertilization (IVF) involving induced superovulation and ICSI, the results of which are shown in Table 3. Of the six blastomeres biopsied in the first cycle, one (B2) failed to transfer to the PCR tube and was not analyzed, while of the remaining five analyzed for the 436delC mutation two (B1 and B4) showed no amplification and three (B3, B6 and B7) were diagnosed as normal (Figure 1b). Analysis of the D3S1038 marker confirmed the genotypes of blastomeres B3 and B7 (Figure 1c), but paternal ADO occurred in blastomere B6 and therefore its genotype could not be determined. Embryos corresponding to blastomeres B3 and B7 were transferred to the uterus but the cycle did not result in pregnancy. In the second IVF cycle a total of four blastomeres were biopsied and analyzed, two blastomeres (B2 and B5) failed to amplify while two (B3 and B7) were positive for the 436delC mutation and judged to be affected. Analysis for the D3S1038 marker confirmed that blastomeres $\mathrm{B} 3$ and $\mathrm{B} 7$ were carriers of the allele segregating with the mutation (Figure 1c), and no embryos were transferred. In the third IVF cycle two blastomeres were biopsied and analyzed, one (B3) showed no 436delC or D3S1038 amplification but the other (B2) was diagnosed as normal in respect to the 436delC mutation and this was confirmed by D3S1038 marker analysis. The embryo corresponding to blastomere $\mathrm{B} 2$ was transferred but the cycle did not result in pregnancy.

Many protocols have been developed for performing preimplantation genetic diagnosis (PGD) for autosomal dominantly inherited cancer syndromes including retinoblastoma (Sutterlin et al., 1999; Xu et al., 2001; Rechitsky et al., 2002; Fiorentino et al., 2003; Girardet et al., 2003), Li Fraumeni (Verlinsky et al., 2001), familial adenomatous polyposis coli (Ao et al., 1998), and neurofibromatosis types 1 and 2 (Abou-Sleiman et al., 2002; Verlinsky et al., 2002). Treatment of most cancer syndromes includes aggressive and invasive surveillance procedures, and drastic surgeries may be necessary to increase life expectancy. On the other hand, incomplete penetrance and variable expressivity is characteristic of these hereditary cancers. In choosing PGD, the parents can avoid the transmission of the mutated gene to the subsequent generation without having to terminate a fetus whose phenotype cannot be predicted. The extent of the variable expressivity of VHL disease is exemplified by the mother (individual I-2, Figure 1a) of patient II-1 who was considered to be unaffected until she was found to be a carrier of the VHL gene 436delC mutation which had previously been identified in her affected son (Rocha, 2003).

Table 3 - Results of pre-implantation diagnosis of Von Hippel-Lindau (VHL) disease during three in vitro fertilization cycles.

\begin{tabular}{|c|c|c|c|c|c|c|c|}
\hline $\begin{array}{l}\text { Cycle } \\
\text { number }\end{array}$ & $\begin{array}{c}\text { MII } \\
\text { oocytes }\end{array}$ & $\begin{array}{c}\text { Number of fertilized } \\
\text { embryos }\end{array}$ & $\begin{array}{c}\text { Number of embryos } \\
\text { analyzed }\end{array}$ & $\begin{array}{l}\text { Blastomere } \\
\text { Id }\end{array}$ & VHL genotype & $\begin{array}{l}\text { D3S1038 } \\
\text { genotype }^{\dagger}\end{array}$ & $\begin{array}{c}\text { Number of embryos } \\
\text { transferred }\end{array}$ \\
\hline \multirow[t]{5}{*}{1} & \multirow[t]{5}{*}{7} & \multirow[t]{5}{*}{6} & \multirow[t]{5}{*}{5} & B1 & na & na & \multirow[t]{5}{*}{2} \\
\hline & & & & B3 & NN & $14 / 18$ & \\
\hline & & & & B4 & na & na & \\
\hline & & & & B6 & NN & $20 / 20$ & \\
\hline & & & & B7 & $\mathrm{NN}$ & $19 / 20$ & \\
\hline \multirow[t]{4}{*}{2} & \multirow[t]{4}{*}{8} & \multirow[t]{4}{*}{6} & \multirow[t]{4}{*}{4} & B2 & na & na & \multirow[t]{4}{*}{ - } \\
\hline & & & & B3 & $\mathrm{N}_{\Delta}$ & $14 / 20$ & \\
\hline & & & & B5 & na & na & \\
\hline & & & & B7 & $\mathrm{N}_{\Delta}$ & $14 / 20$ & \\
\hline \multirow[t]{2}{*}{3} & \multirow[t]{2}{*}{5} & \multirow[t]{2}{*}{3} & \multirow[t]{2}{*}{2} & B2 & NN & $14 / 18$ & \multirow[t]{2}{*}{1} \\
\hline & & & & B3 & na & na & \\
\hline
\end{tabular}

${ }^{\dagger}$ Numbers refer to alleles in Figure 1. ${ }^{\dagger}$ Paternal ADO. $\mathrm{N}=$ normal VHL allele; $\Delta=436 \mathrm{delC}$ mutation; na = no amplification. 
A previous report of PGD for VHL disease used a combination of mutation detection and segregation analysis of one microsatellite, D3S100 (Rechistsky et al, 2002). More recently, this approach has lead to the birth of two children free of VHL mutations (Verlinsky and Kuliev, 2006). In the present paper we have described in detail a novel PGD protocol, relying on the analysis of the specific $V H L$ mutation and up to two microsatellite markers, to detect VHL disease in a large number of families with this disease.

Multiplex-nested PCR was used to amplify a gene segment encompassing the 436delC mutation, as well as the D3S1038 and D3S1317 markers. In single cells isolated from the affected father the $436 \mathrm{delC}$ mutation showed $12 \%$ ADO whereas D3S1038 showed only 8\% (Table 2). Allelic drop-out is a major obstacle when performing PGD of monogenic diseases because it can result in the transfer of embryos affected by a dominant inherited disease. To overcome this we added microsatellite marker analysis to the PGD protocol because this analysis can easily detect ADO and hence produce a correct interpretation of the results. For example, in our study D3S1038 microsatellite analysis detected paternal ADO in a blastomere diagnosed as normal by 436delC mutation analysis (first IVF cycle, blastomere B6, Table 3). This meant that the occurrence of ADO in the mutation analysis could not be excluded, rendering the final genotype undetermined and the corresponding embryo not suitable for transfer.

In summary, the couple was submitted to in vitro fertilization involving three intracytoplasmic spermatozoa injection (ICSI) and preimplantation genetic diagnosis (PGD) cycles and a total of 12 embryos were obtained. We were able to biopsy 11 embryos, although there may have been failure of blastomere transfer to the PCR tube in the 5 instances where none of the loci were amplified (Table 3). Three embryos were diagnosed as normal and transferred, but none of the cycles resulted in pregnancy. It is important to note that the viability of human embryos has been shown to be unaffected by PGD (Cieslak-Janzen et al., 2006). In conclusion, the protocol we have developed for PGD analysis of Von Hippel-Lindau disease can be used in families informative for either the D3S1038 or D3S1317 polymorphic markers (or both markers), independent of the mutation present.

\section{Acknowledgments}

This work was supported by grants from the Brazilian agencies Fundação de Amparo à Pesquisa do Estado de São Paulo (FAPESP - CEPID Centro de Estudos do Genoma Humano) and Conselho Nacional de Desenvolvimento Científico e Tecnológico (CNPq).

\section{References}

Abou-Sleiman PM, Apessos A, Harper JC, Serhal P, Winston RM and Delhanty JD (2002) First application of preimplantation genetic diagnosis to neurofibromatosis type 2 (NF2). Prenat Diagn 22:519-524.

Ao A, Wells D, Handyside AH, Winston RM and Delhanty JD (1998) Preimplantation genetic diagnosis of inherited cancer: Familial adenomatous polyposis coli. J Assist Reprod Genet 15:140-144.

Cieslak-Janzen J, Tur-Kaspa I, Ilkevitch Y, Bernal A, Morris R and Verlinsky Y (2006) Multiple micromanipulations for preimplantation genetic diagnosis do not affect embryo development to the blastocyst stage. Fertil Steril 85:1826-9.

Decker HJ, Weidt EJ and Brieger J (1997) The von Hippel-Lindau tumor suppressor gene. A rare and intriguing disease opening new insight into basic mechanisms of carcinogenesis. Cancer Genet Cytogenet 93:74-83.

Fiorentino F, Magli MC, Podini D, Ferraretti AP, Nuccitelli A, Vitale N, Baldi $\mathrm{M}$ and Gianaroli L. The minisequencing method: An alternative strategy for preimplantation genetic diagnosis of single gene disorders. Mol Hum Reprod 9:399410.

Girardet A, Hamamah S, Anahory T, Dechaud H, Sarda P, Hedon B, Demaille J and Claustres M (2003) First preimplantation genetic diagnosis of hereditary retinoblastoma using informative microsatellite markers. Mol Hum Reprod 9:111-116.

Jones MH, Yamakawa K and Nakamura Y (1992) Isolation and characterization of 19 dinucleotide repeat polymorphisms on chromosome 3p. Hum Mol Genet 1:131-133.

Latif F, Tory K, Gnarra J, Yao M, Duh FM, Orcutt ML, Stackhouse T, Kuzmin I, et al. (1993) Identification of the von Hippel-Lindau disease tumor suppressor gene. Science 260:1317-1320.

Li H, Schmidt L, Duh FM, Wei MH, Latif F, Stackhouse T, Lerman MI, Zbar B and Tory K (1993) Three polymorphic dinucleotide repeats near the von Hippel Lindau (VHL) disease gene on human chromosome 3: D3S587; D3S1317; D3S1435. Hum Mol Genet 2:1326.

Lonser RR, Glenn GM, Walther M, Chew EY, Libutti SK, Linehan WM and Oldfield EH (2003) von Hippel-Lindau disease. Lancet 361:2059-2067.

Maher ER, Iselius L, Yates JR, Littler M, Benjamin C, Harris R, Sampson J, Williams A, et al. (1991) Von Hippel-Lindau disease: A genetic study. J Med Genet 28:443-447.

Maher ER, Yates JR, Harries R, Benjamin C, Harris R, Moore AT and Ferguson-Smith MA (1990) Clinical features and natural history of von Hippel-Lindau disease. Q J Med 77:11511163.

Miller SA, Dykes DD and Polesky HF (1988) A simple salting out procedure for extracting DNA from human nucleated cells. Nucleic Acids Res 16:1215.

Neumann HP and Wiestler OD (1991) Clustering of features and genetics of von Hippel-Lindau syndrome. Lancet 338:258.

Palermo G, Joris H, Devroey P and Van Steirteghem AC (1992) Pregnancies after intracytoplasmic injection of single spermatozoon into an oocyte. Lancet 340:17-18.

Rechitsky S, Verlinsky O, Chistokhina A, Sharapova T, Ozen S, Masciangelo C, Kuliev A and Verlinsky Y (2002) Preimplantation genetic diagnosis for cancer predisposition. Reprod Biomed Online 5:148-155. 
Richards FM, Payne SJ, Zbar B, Affara NA, Ferguson-Smith MA and Maher ER (1995) Molecular analysis of de novo germline mutations in the von Hippel-Lindau disease gene. Hum Mol Genet 4:2139-2143.

Rocha JCC, Silva RLA, Mendonça BB, Marui S, Simpson AJG and Camargo AA (2003) High frequency of novel germline mutations in the VHL gene in the heterogeneous population of Brazil. J Med Genet 40:e31.

Sutterlin M, Sleiman PA, Onadim Z and Delhanty J (1999) Single cell detection of inherited retinoblastoma predisposition. Prenat Diagn 19:1231-1236.

Verlinsky Y, Rechitsky S, Verlinsky O, Xu K, Schattman G, Masciangelo C, Ginberg N, et al. (2001) Preimplantation diagnosis for p53 tumour suppressor gene mutations. Reprod Biomed Online 2:102-105.
Verlinsky Y and Kuliev A (2002) Atlas of Preimplantation Genetic Diagnosis. Parthenon, New York and London, pp 1522.

Verlinsky Y, Rechitsky S, Verlinsky O, Chistokhina A, Sharapova T, Masciangelo C, Levy M, et al. (2002) Preimplantation diagnosis for neurofibromatosis. Reprod Biomed Online 4:218-222.

Verlinsky Y and Kuliev A (2006) Practical Preimplantation Genetic Diagnosis. Springer, London and New York, pp 198.

Xu K, Shi Z, Yuan H, Cholst I and Rosenwaks Z (2001) Diagnosis of retinoblastoma mutation by both gel electrophoresis and fluorescent fragment analysis. Fertile Steril 763 (Suppl. 1):S237-S238.

Associate Editor: Emmanuel Dias Neto 